\title{
Electronic Books Impact Global Environment—An Empirical Study Focus on User Perspectives
}

\author{
Chiang-nan Chao ${ }^{1}$, Leonora Fuxman ${ }^{1} \&$ I. Hilmi Elifoglu ${ }^{1}$ \\ ${ }^{1}$ Tobin College of Business, St. John's University, New York, USA \\ Correspondence: Chiang-nan Chao, Tobin College of Business, St. John's University, 8000 Utopia Parkway, Jamaica, \\ New York, USA. E-mail: chaoc@stjohns.edu
}

Received: February 4, 2013

Accepted: March 8, $2013 \quad$ Online Published: April 27, 2013

doi:10.5430/jms.v4n2p52

URL: http://dx.doi.org/10.5430/jms.v4n2p52

\begin{abstract}
This study examines the differences in behavior perspectives between the users of ebooks and printed books. The study focuses on a range of behavioral issues about ebook adoptions. These managerial issues will not only be strategic to the publishing industry and the paper industry's bottom lines, but will also impact our future environment. The study finds the respondents spent slightly more time on reading printed books compare to ebooks. Digital books, however, have significant advantages in many aspects over the printed books. Although ebook adoption is a rapidly growing trend, it still lacks some of the advantages of the traditional printed books, e.g. there are many different and incompatible platforms for the usage of ebooks, and the consumers do not need to have the concern of a copyright for printed books. The findings of this preliminary study suggest that publishers may need to promote ebooks more aggressively and not only as a way to reduce the cost, but also as a way to preserve our global environment.
\end{abstract}

Keywords: environment, paper industry, electronic books, digital books, printed books vs. electronic books

\section{Introduction}

\subsection{Emergence of the Problem}

The paper has been around for over two thousand years. Ever since the Chinese first invented paper with linen and straw, it quickly outdated books made of bamboo, silk, skin, and papyrus. Today's paper industry relies heavily on trees for its products. It was reported that primary forest area was reduced globally by 60,000 square kilometers per year, about the size of Ireland [greenfacts.org, 2009]. The paper industry and other non-lumber products consumed 1.6 billion trees, or 300 million tons of paper each year which equals to 43 percent of the total tree consumption globally [understory.ran.org, 2008]. The U.S., which contains only 5 percent of the world's population, uses 30 percent of all paper, and the forest and paper products industry generates \$200 billion dollars in sales every year, accounting for 7 percent of the total manufacturing output of the United States. About 28 percent of all wood cut in the U.S. is used for papermaking [ecology.com, 2011]. Deforestation due to paper and other industries' needs has alarmingly endangered our environment and the nature [Parsons, 2012].

Ebooks that do not use paper are emerging from an almost zero ten years ago, to today's total sales of $\$ 2,079$ million US\$ in 2012 and have grasped $31.85 \%$ of the total sales of books [mediabistro.com, 2013]. E-book sales are expected to surge to $\$ 2.7$ billion by the end of 2013 with a compound annual growth rate of 72 percent, according to Yankee Group projections [Trachtenberg, 2011].

The emergence of ebooks [and all other digital forms of publishing, i.e. newspaper, magazines, etc] is challenging the traditional way of publishing and reading. The academic research in this area is still quite limited due to this emerging nature of ebooks. Newsweek, with its 80 year history, recently announced a complete seizure of its printed form, while retaining only its digital form [Hagey and Fitzgerald, 2012]. Plenty of other printed publications, i.e. PC Magazine, Gourmet, and SmartMoney, etc. have embraced digital-only strategies, encouraged by the proliferation of digital tablets and the growth in digital advertising over the past two years [Gillette, 2012].

\subsection{Need to Explore the Problem}

This study, in an empirical setting, examines the users' preferences, in order to provide some managerial insights on this digital publishing market: what consumers prefer and how they make purchasing decisions. The focus is mainly on the issues of the digital publishing and printed publishing. In addition, this study attempts through an empirical 
exploration to investigate if there were any differences resulted from the consumers' viewpoints between ebooks and printed books, centering on product offerings and their qualities, price (including promotions), deliveries and usability. This study aims to explore the impact of the emerging ebooks on the publishing industry, on book readers and their reading behavior, on our society and on general global environment.

\subsection{Review of Literature}

In the recent years, the traditional printed publishing industry is facing an emerging challenge from digital publishing, quite resembling the competition between filmed cameras and digital cameras, even though the digital publishing represents only a small fraction of the total publishing industry's sales at the moment. However, some of the printed publishing, i.e. newspapers, have experienced a sharp decline recently. Figure 1 documents the emerging sales of printed books and ebooks in the U.S. from combined sources between 2002 and 2013. It is predicted that ebook sales will reach $45 \%$ market share in the U.S. book market.

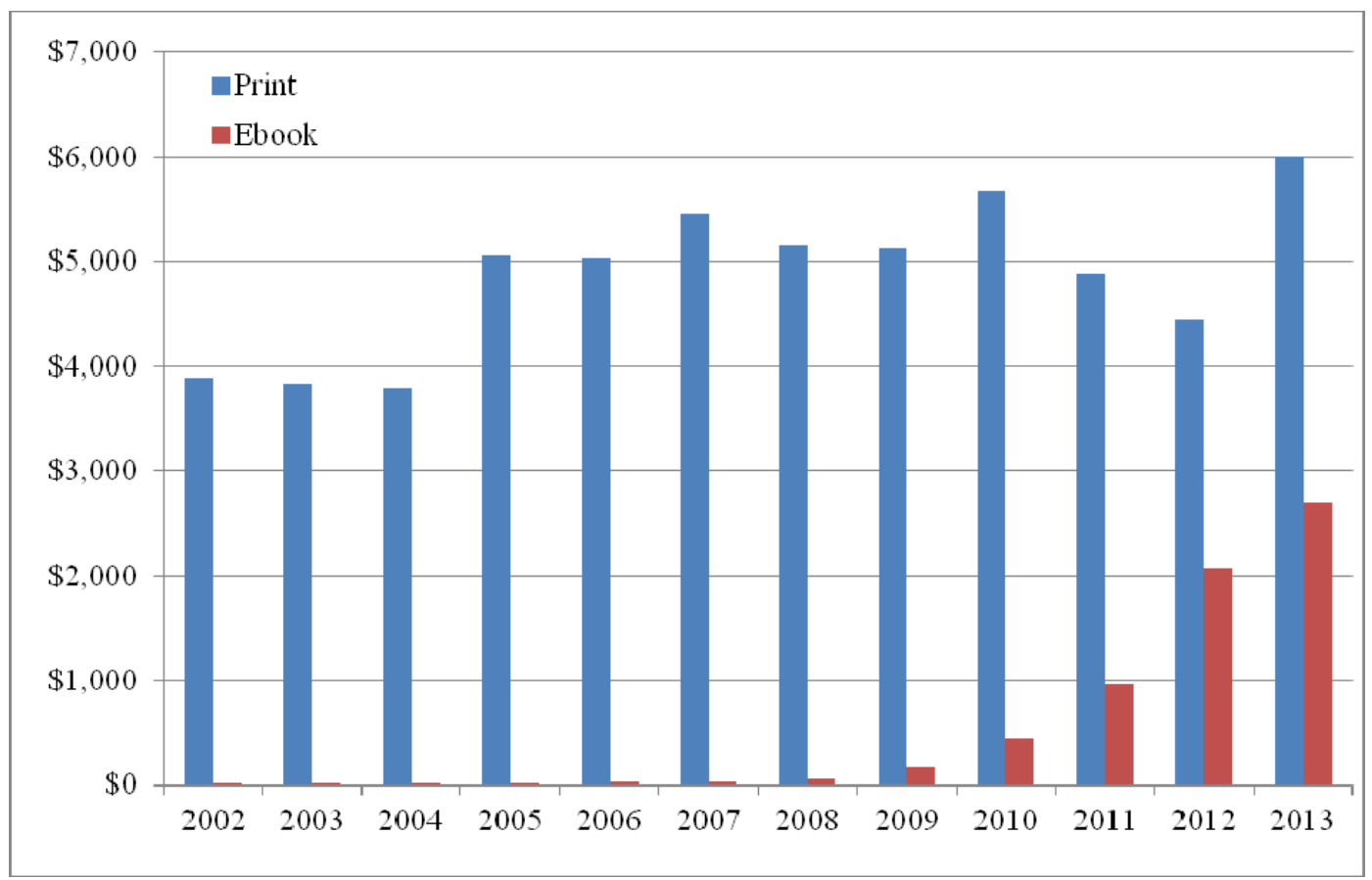

Figure 1. U.S. printed book sales vs. ebook sales, in millions of US\$

Source: http://www.mediabistro.com/ebooknewser/aap-reports-ebook-sales-up-72-in-december_b20563

While the revenues in digital publishing are growing rapidly, the total sales are still lugging far below that of printed publishing. Some of the printed publishing, i.e. newspapers and magazines have experienced a sharp decline in the recent years. Contrary to traditional printed publishing, the digital publishing market needs both reading gadgets and contents. As far as the selection of digital gadgets, consumers have quite a number to choose from. Ranging from tiny gadgets, such as smartphones to specially manufactured ebook readers, i.e. Amazon's Kindles and Barnes and Noble's Nooks, etc, to generic tablets like Apple's iPad, netbooks and laptops, and desktop computers, choices are abundant. There are no universal standards for the ebooks, just like with printed books which have a variety of type settings. For many people, the problem with ebooks is that they come with limitations. Ebooks bought today from Amazon.com, for example, can be read mostly on Amazon's Kindle. The popularity of these specialized gadgets for reading ebooks may decline in the years to come. Figure 2 presents the prediction of ereaders sales in the next few years. Some restrictions on the use of ebooks are likely to remain a fact of life for some time to come. Because of this, many potential ebook customers shy away from jumping on the trend of ebooks and ereaders. In addition, there is no single technology standard for ebooks, even though the front runners like Amazon tend to dominate in the nascent market. Many publishers are concerned about incompatibility of these gadgets, and naturally have to be anxious to find out which gadget would eventually become dominant, since the choice of a wrong format would have a profound impact. Some developers believe that there is a limit to people's appetite for new digital media. The dominant operating systems for smartphones and tablets are currently either Apple's or Android of Google, while Windows 8 is emerging with some uncertain market potentials [Warner, 2011, Graham, 2012, Vance, 2013, Coker, 2013]. 


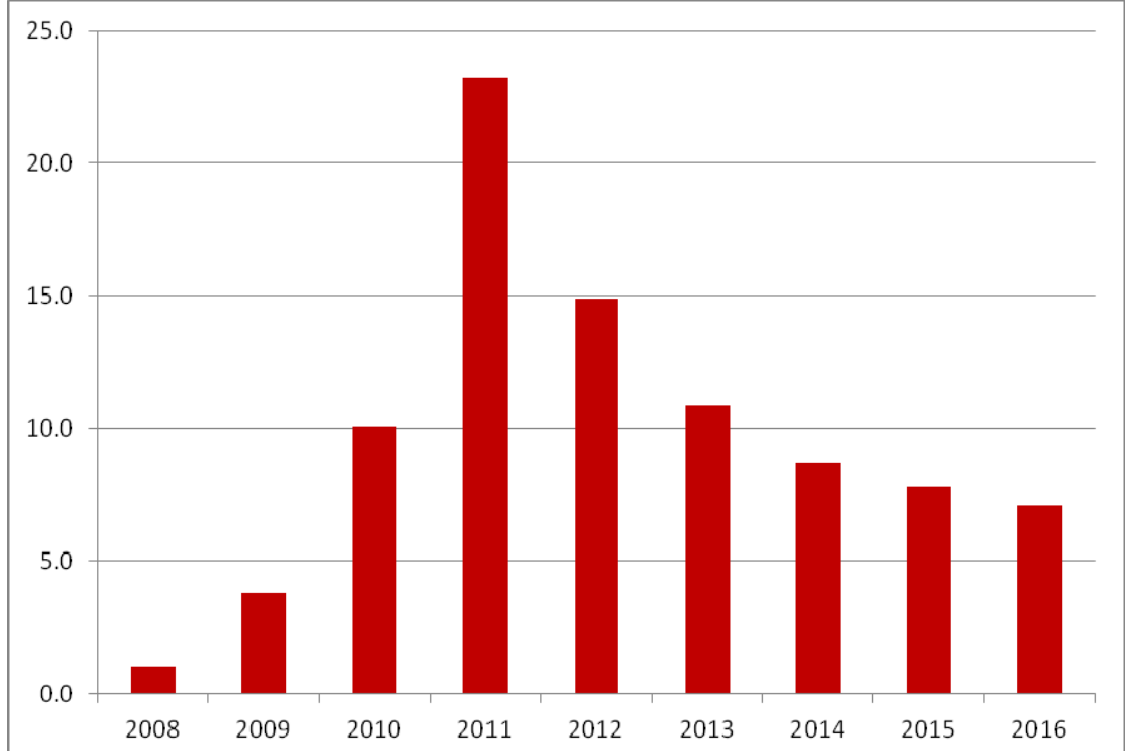

Figure 2. Ereaders sales' prediction worldwide, in millions of units

Source: http://www.statista.com/statistics/184476/sales-of-electronic-readers-worldwide-forecast/

To make the situation more complicated, often digital gadget makers, publishers, and book retailers do not agree with one another so it is difficult to develop new business models for profit-cost sharing. Dominant players often pressure others to go along with their terms. Amazon has tussled with publishers recently over ebook prices, but a new pricing model that is emerging could improve Amazon's profit margin on ebooks for any e-readers. Publishers will set prices for many ebooks, with retailers such as Amazon and Apple taking 30\% of the revenue. This pricing model guarantees a profit on every sale. Amazon's previous policy of discounting new ebook best sellers at $\$ 9.99$ typically resulted in losses, since it paid more than $\$ 9.99$ for those books. What's more, Amazon is years ahead of Apple in building relations with the publishing industry, being one of the biggest print-book retailers in the nation. Amazon now offers more than 450,000 ebooks, and has access to more than 1.8 million free out-of-copyright titles. Apple has said it will start with 60,000 titles from five of the largest publishing houses. A new approach proposed by Apple intends to let every player in the distribution channel to collect a fee or commission. Apple's app stores enable the company to collect commission on every book or magazine sold, and the stores generated over $\$ 1.1$ billion in eighteen months to February 2011. Apple is now requiring publishers that conduct sales of content-which includes books as well subscriptions - to offer a way to do so within apps, which will be handled by the iTunes billing system. The policy, which the company says isn't new, was cited in Apple's rejection of a Sony Corp. app for reading ebooks last year. To sell more of its Kindle e-readers, Amazon offered many titles below cost, including best sellers at \$9.99. Publishers disliked the strategy, fearing it would make it harder for them to sell hard covers at higher prices. When Apple entered the fray, it offered publishers the ability to set their own prices. Under the Apple arrangement, known as "agency pricing," publishers received $70 \%$ of the retail price and Apple took a $30 \%$ commission. But Apple also insisted that publishers couldn't sell for less to any of its rivals. The publishers then were able to impose the same model on Amazon [Trachtenberg, 2010; Fowler \& Trachtenberg, 2010; Kane and Vascellaro, 2011; Checkler, et al, 2011; Catan and Trachtenberg, 2012].

Barnes \& Noble Inc. has stepped onto the nascent digital-book battleground with Amazon and Android based smart phones and tablets, saying it would launch its own ebookstore with bestsellers priced at $\$ 9.99$, in line with its rivals. It would offer more than 700,000 titles, including more than 500,000 public domain books from Google Inc., and that it expects to be able to offer more than one million titles by July 2010. Book formats supported by the new Barnes \& Noble ebookstore include those that can be viewed on Apple Inc.'s iPhone and iPod Touch, BlackBerry smartphones and most Windows and Mac computers. However, titles bought through Barnes \& Noble's ebookstore are not compatible with Sony's Reader or Amazon.com's Kindle ebook reader, the two dominant e-readers in the U.S. market. The largest booker retailer declined to share the readers' information with publishers [Rich and Stone, 2010; Trachtenberg, 2010; Bilton, 2011; Greenfield, 2012].

Despite the complications in the publishing market, both resellers and publishers want to provide their customers with an alternative of ebooks. In addition to bringing about new titles in a digital format, they republish old titles by big-name authors. These approaches further enable the demand growth of ebooks [Kane and Fowler, 2010]. 
Although printed books and magazines are in the low technology spectrum compared with digital publications, the screens won't go blank, nor would they be transacted a virus, and they have been around for thousands of years. However, they are heavy and expensive. For example, college students pay $\$ 700$ to $\$ 900$ a semester for books in addition to the already high expenses in tuition and other fees [Foderaro, 2010].

Motivated by the fast growing trend of ebook adoptions and very limited research available up-to-date, this paper thus attempts to shed some light onto the nature of the challenges in digital printing industry as viewed by consumers. Within empirical setting, this study was designed to compare consumer use of digital and printed books. The variables incorporated in this study included, along with others, those related to the consumer choice of book formats, reading devices, convenience, and technical issues as they relate to ebooks. All variables were selected from the available literature review to represent most issues related to the usage and preferences in ebooks compared to printed books. Although this study is a preliminary one, findings are suggestive of the need of more intensive promotion of ebooks by publishers, not just as a cost reducing strategy, but also as a way to becoming more "green" and supportive of the global environment.

Chao and Lu conducted an empirical study on ebooks, and it may be the first academic work done in this area. They cover eleven variables related to consumer book purchase decision making. Their study finds that ebooks are more appealing for college students than the printed books. However, their study has very limited sample size, and any generalization of their study may be very limited [Chao and Lu, 2011].

\section{Method}

With the focal questions in mind, this research studied the viewpoints of consumers with regards to how they view ebooks as compared to the traditional printed books. The books include all books, magazines, newspapers, and other related publications. A survey was developed to investigate the consumer preferences on products and their quality, price and promotion, as well as deliveries. The following variables were based on literature reviews.

\subsection{Variable Selection and Survey Questionnaire}

Stemmed from literature review, the following variables affect consumers' preferences in how and where they make their purchasing decisions:

1). easy to obtain

2). low cost of possession of the reading materials

3). easy to read

4). attractive prices for possessing contents

5). easy to carry around

6). weights

7). easy to share with others

8). need of special reading instruments, i.e. kindle, eReader, iPad, Galaxy, Nooks, etc.

9). free delivery or delivery incentives

10). compatibility in the formats

11). concern with copyright

These variables were served as cores in a survey questionnaire designed to collect the consumers' opinions, paired both in digital books and printed books. The questionnaire also included the background information of the respondents.

2.2 Sample, Data Collection, Measurements, and Hypotheses

Due to the exploratory nature of this empirical study, the questionnaires were distributed to college students and some professors in a large university campus in the Northeast for a convenient sampling. Since these respondents tended to browse websites and download digital books regularly, they would provide some meaningful insights to the publishing industry and book readers. The respondents were asked to evaluate the selected variables on a five point Likert scale, with $5=$ strongly prefer, $4=$ prefer, $3=$ neutral, 2 not prefer, and $1=$ strongly not prefer.

The hypotheses for this research were to find if there were significant differences from the consumers' viewpoints between ebooks and printed books. The hypotheses for this study state:

Hypothesis 1. There is no significant difference in "easy to obtain" between ebooks and printed books.

Hypothesis 2. There is no significant difference in "low cost of possession" of the reading materials between ebooks and printed books.

Hypothesis 3. There is no significant difference in "easy to read" between ebooks and printed books. 
Hypothesis 4. There is no significant difference in "attractive prices for possessing contents" between ebooks and printed books.

Hypothesis 5. There is no significant difference in "easy to carry around" between ebooks and printed books.

Hypothesis 6. There is no significant difference in "weights" between ebooks and printed books.

Hypothesis 7. There is no significant difference in "easy to share with others" between ebooks and printed books.

Hypothesis 8. There is no significant difference in "need of special reading instruments, i.e. kindle, eReader, iPad, Galaxy, Nooks, etc." between ebooks and printed books.

Hypothesis 9. There is no significant difference in "free delivery or delivery incentives" between ebooks and printed books.

Hypothesis 10. There is no significant difference in "compatibility in the formats" between ebooks and printed books.

Hypothesis 11. There is no significant difference in "concern with copyright" between ebooks and printed books.

Alternatively, there are significantly different preferences in these variables between ebooks and printed books from the consumers' viewpoints.

\subsection{Test of Hypotheses-Wilcoxon Test}

When two samples are involved and the values for each sample are collected from the same individuals (that is, each individual gives two values, one for each of the two categories), or the samples come from matched pairs of individuals, the Wilcoxon signed-rank test can be used to test hypotheses. This test is a non-parametric statistical hypothesis test used when comparing two related samples, matched samples, or repeated measurements on a single sample to assess whether their population mean ranks differ (i.e. it is a paired difference test). It can be used as an alternative to the paired Student's t-test, t-test for matched pairs, or the t-test for dependent samples when the population cannot be assumed to be normally distributed. The Wilcoxon test assumes: 1. Data are paired and come from the same population; 2. Each pair is chosen randomly and independent; and 3. The data are measured on an interval scale (ordinal is not sufficient because differences are recorded), but need not be normal. The nulls should be rejected if the significance level is less than or equal to five percent in these criteria, in another word, five percent of the paired sample the Wilcoxon test two-tailed probability level signifies the preferences for ebooks vs. printed books [Hamburg, 1977; Conover, 1980; Davis and Cosenza, 1985; SPSSX, 2002; Wikipedia, http://en.wikipedia.org/wiki/Wilcoxon_signed-rank_test].

\section{Results}

Over 607 respondents were surveyed at a college campus in the Northeastern U.S., with 228 completed responses for analyses, representing 37.56 percent of the total surveyed. Table 1 presents the general background information of the respondents. All the respondents had experience in downloading digital articles and/or books from websites. Table 2 presents an excerpt from the survey related to online activities associated with ebooks, digital newspapers, digital magazines, and gadgets of ereaders.

3.1 Backgrounds of the Respondents

Table 1. Backgrounds of the respondents

\begin{tabular}{lcc}
\hline Demographic issues & Groups & Valid \% \\
\hline 1. Age & $<18$ & 0.9 \\
& $18-35$ & 97.4 \\
2. gender & $>35$ & 1.8 \\
& Male & 57.9 \\
3. Family annual income & Female & 42.1 \\
& $<\$ 30 \mathrm{k}$ & 22.1 \\
& $\$ 30-50 \mathrm{k}$ & 16.4 \\
& $\$ 50-75 \mathrm{k}$ & 23.9 \\
4. Education & $>\$ 75 \mathrm{k}$ & 37.6 \\
& high school & 12.8 \\
& College & 79.7 \\
5. Marital status & Graduate & 7.5 \\
& Married & 33.6 \\
& Single & 66.4 \\
\hline
\end{tabular}

Source: original 


\subsection{Issues Related to Reading}

Table 2 presents an excerpt from the survey related to online activities associated with ebooks, digital newspapers, digital magazines, and gadgets of ereaders.

Table 2. Issues related to reading

\begin{tabular}{lcc}
\hline & Response & Valid \% \\
\hline 6a. have you ever read any book, newspapers, and magazines on & Yes & 90.4 \\
computer or on any digital form? & No & 9.6 \\
6b. do you have any e-readers, i.e. Amazon's Kindle, iPad, Nook, Sony's & Yes & 21.9 \\
e-readers, or any other brand? & No & 78.1 \\
\hline
\end{tabular}

Source: original

\subsection{Wilcoxon Test Results}

Table 3 presents the Wilcoxon test results. Significant differences are found in ten of the eleven variables.

Table 3. Wilcoxon test results for all variables

\section{1. easy to obtain}

2. low cost of possession of the reading materials

3. easy to read

4. attractive prices for possessing contents

5. easy to carry around

6. weights

7. easy to share with others

8. need of special reading instruments, i.e. kindle, iPad, Galaxy, Nooks, etc.

9. free delivery or delivery incentives

10. compatibility in the formats

11. concern with copyright

\begin{tabular}{ll}
-3.491 & 0.00 \\
-6.190 & 0.00 \\
-3.877 & 0.00 \\
-3.703 & 0.00 \\
-8.164 & 0.00 \\
-2.127 & 0.03 \\
-4.925 & 0.00 \\
-2.599 & 0.01 \\
-2.396 & 0.02 \\
-2.089 & 0.04 \\
-1.720 & 0.09 \\
\hline
\end{tabular}

* Significance level is 2-tailed. Source: original.

\section{Discussions}

\subsection{Managerial Implications and Recommendations}

The Wilcoxon Test results reject ten of the null hypotheses; therefore, the study concludes that there are statistically significant differences from the consumers' viewpoints between electronic books and printed books, when the significance levels are less than $5 \%$ in the ten out of the total eleven variables. These variables are: easy to obtain; low cost of possession of the reading materials; easy to read; attractive prices for possessing contents; easy to carry around; weights; easy to share with others; need of special reading instruments, i.e. Kindle, eReader, iPad, Galaxy, Nooks, etc.; free delivery or delivery incentives; compatibility in the formats. No statistically significant difference is found in only one variable, concern with copyright.

The test results also indicate that in nine out ten variables with significant differences in the respondents' preference, ebooks are favored over printed books. These variables include: easy to obtain; low cost of possession of the reading materials; attractive prices for possessing contents; easy to carry around; weights; easy to share with others; need of special reading instruments, i.e. Kindle, eReader, iPad, Galaxy, Nooks, etc.; free delivery or delivery incentives; compatibility in the formats. This finding may suggest to the publishing industry, book authors and readers, i.e. students and professors alike, the need to continuously focus on promoting and improving ebooks in these areas.

The adoption of ebooks has emerged as a great challenge to the printed book, not only because of its advantages, but also because it helps make our environment greener. Publishers, book retailers, professors, students, and all readers should move to adaptation of ebooks in the future to protect our environment.

Additionally, the test results confirm that in one area: easy to read, the sample respondents prefer printed books over ebooks. This illustrates that even with numerous convenience features; ebooks may never completely outweigh some key advantages of printed books. Consequently, ebooks may never replace printed books. However, it is undeniably 
clear that publishers will need to continue to improve readability of ebooks in the future, as this important trend will not likely to disappear in the future.

The results are different as compared to Chao and Lu's study, as their respondents do not concern with different formats of ebooks, while this study shows that the consumers do not concern with copyright. This may indicate that it is the publishers' concern for the copyright, not users; while users do concern with different formats of ebooks that make reading more difficult when users use different gadgets.

\subsection{Limitations and Future Research}

The academic research that focuses on ebooks is very limited, and it may take some years before significant research findings are available. As a preliminary and exploratory research, this study offers some initial glimpses of the fundamental aspects of the differences between ebooks and the traditional publishing industry as they relate to consumer reading behavior, our society in general, and our global environment.

More in depth research work is needed in the future. Do consumers really need specialized reading gadgets, or would they rather use generic tablets or computers? Some of the respondents commented consumers might not need to spend much money on buying specially designed digital reading gadgets, such as Amazon's Kindles or Barnes and Noble's Nooks. Others commented that the sizes of gadgets could be a factor for purchasing decision: 10" of tablet computer like iPads, or Samsung's Galaxies, vs. much smaller screens on smartphones, and/or battery life. These technological issues should also be addressed in the future research. Specially designed reading gadgets seem be diminishing, as per recent market trends, so consumers may focus their attentions on those tablets that offer a lot more features than reading-only devices.

Since this study focused on surveying only college students, staff and professors, caution must be exercised in trying to generalize the outcomes of the research. Larger, general population may have more significant variations in computer skills and use than college students/professors have, which may skew the results of a similar survey. Of course, since this study relied on a still small convenient sample, though far larger than Chao and Lu's previous study, once again, generalizations must be made cautiously.

\section{References}

Bilton, N. (2011). A Race between Digital and Print Magazines, NY Times, February 4.

Catan, T., \& Trachtenberg, J. A. (2012). Talks Quicken Over E-Book Pricing. The Wall Street Journal, April 4.

Chao, C.N., \&Lu, F. (2011). Emergence of Ebooks and Related Managerial Issues: a Preliminary Study. International Journal of Business, Marketing, and Decision Sciences, 4(1), 117-126.

Checkler, J., Morath, E., \& Trachtenberg, J. A. (2011). Borders Files for Chapter 11 Bankruptcy Protection. The Wall Street Journal, February 16.

Coker, M. (2013). Mark Coker's 2013 Book Publishing Industry Predictions - Indie Ebook Authors Take Charge. Huffington Post, $\quad$ December $25 . \quad$ Retrieved from http://www.huffingtonpost.com/mark-coker/2013-book-publishing-indu_b_2352895.html

Conover, W. J. (1980). Practical Nonparametric Statistics (2nd ed.). New York: John Wiley \& Sons, pp. 213-337 \& pp. 344-384.

Davis, D., \& Cosenza, R. M. (1985). Business Research for Decision Making. Boston, Kent Publishing Company.

Foderaro, L. W. (2010). In a Digital Age, Students Still Cling to Paper Textbooks. NY Times, October 19.

Fowler, G. A., \& Trachtenberg, J. A. (2010). Barnes \& Noble Adds Color, Web to Nook. The Wall Street Journal, October 27.

Gillette, F. (2012). Digital Media Dreams, Elusive Profits. Business Week, October 25.

Graham, J. (2012). Apple sells 3 million new iPads in 3 days. USA TODAY, March 19.

Greenfield, J. (2012). Barnes \& Noble Has No Imminent Plans to Share More Data with Publishers. Digital Book World, March 16.

Hagey, K,, \& Fitzgerald, D. (2012). Newsweek to End Print Edition. The Wall Street Journal, October 18.

Hamburg, M. (1977). Statistical Analysis for Decision Making (2nd ed.). Harcourt Brace Jovanovich, Inc., New York, pp. 219-538. 
Kane, Y. I., \& Fowler, G. A. (2010). For Amazon, Arrival of the iPad Opens Door to More digital book Sales. The Wall Street Journal, April 2.

Kane, Y. I., \& Vascellaro, J. E. (2011). Apple to Tighten Control on Content. The Wall Street Journal, February 3.

Parsons, C. (2012). Deforestation in Indonesia Caused by the Orang-utans Lost their Homes Sad Tragic Death. Mailonline.com, April $\quad 4.4$ Retrieved from http://www.dailymail.co.uk/news/article-2118376/Filmmakers-heart-wrenching-documentary-shows-tragic-fina 1-hours-orangutans-life.html

Retrieved 2008, from http:/understory.ran.org/2008/04/22/how-many-trees-are-cut-down-every-year/

Retrieved 2011, from http://www.ecology.com/2011/09/10/paper-chase/http://www.opene-book.org/doc_library/industrystats.htm

Retrieved 2009, from http://www.greenfacts.org/en/forests/index.htm\#2

Retrieved 2012, from http://www.opendigital book.org/doc_library/industrystats.htm

Retrieved 2012, 2012, from http://www.mediabistro.com/ebooknewser/aap-reports-ebook-sales-up-72-in-december_b20563

Rich, M., \& Stone, B. (2010). Digital book Price Increase May Stir Readers' Passions. NY Times, February 11. SPSS $^{\mathrm{X}}$. (2002). Advanced Statistics, 7.5. Chicago, IL: SPSS Inc.

Trachtenberg, J. A., \& Fowler, G. A. (2010). Digital book Pricing Put Into Turmoil. The Wall Street Journal, January 30.

Trachtenberg, J. A. (2010). New Digital Book Pricing Model Adopted in Fits and Starts. The Wall Street Journal, April 1.

Trachtenberg, J. A. (2011). E-Book Readers Face Sticker Shock. The Wall Street Journal, December 15.

Vance, A. (2013). HP CEO Whitman Dubs Windows 8 a Work in Progress. Business Week, January 11.

Warner, M. (2011). Tablets Sapping PC Demand, Gartner Says. The Wall Street Journal, March 3.

Wikipedia. Retrieved from http://en.wikipedia.org/wiki/Student's_t $t$-test 